\title{
INFLUENCE OF THE AMOUNT OF FOOD RESOURCES IN THE FORAGING BEHAVIOR OF Nasutitermes corniger (MOTSCHULSKY)
}

\author{
INFLUENCIA DA QUANTIDADE DE MADEIRA NO COMPORTAMENTO DE \\ FORRAGEAMENTO DE Nasutitermes corniger (MOTSCHULSKY)
}

\author{
Thiago Sampaio de SOUZA ${ }^{1^{*}}$; Vinícius Siqueira GAZAL ${ }^{2}$; \\ Elen de Lima AGUIAR-MENEZES ${ }^{2}$; Vinicius José FERNANDES ${ }^{1}$; \\ Aline Machado LEITE-MAYERHOFER ${ }^{1}$ \\ 1. Postgraduate Program in Phytosanitary and Applied Biotechnology, Federal Rural University of Rio de Janeiro, Seropédica, RJ, \\ Brazil; 2. Department of Entomology and Phytopathology, Federal Rural University of Rio de Janeiro, Seropédica, RJ, Brazil. \\ *Corresponding author: thiagosampaio.agro@gmail.com
}

\begin{abstract}
Food scarcity or abundance are factors regulating termites' foraging behavior in general. The aim of the present study is to evaluate the influence of four amounts of Eucalyptus grandis on foraging behavior events shown by worker and soldier of Nasutitermes corniger during laboratory tests. The tests were carried out with adult and active $N$. corniger colonies found in nests collected in the field, which were stored in glass cubes connected to the test arenas. Four different amounts of wood blocks were used in the tests and each amount concerned a treatment and defined a different experimental group: 1, 2, 3 and 4 blocks/arenas, with 5 repetitions. Each test lasted 60 minutes and consisted in observing, or not, the occurrence of behavioral events shown by foragers when they had contact with the treatment. The duration of each event was recorded, whenever it was observed. The number of recruited foragers and the number of workers consuming the blocks were recorded at the end of each test applied to each treatment. Nasutitermes corniger presented the three behavioral events in all treatments; however, there was not significant difference between treatments in the occurrence of the two first events, in the time taken from test start to the occurrence of a new event, in the number of recruited termites and in the number of gnawing workers. Only workers' mass recruiting was influenced by the amount of wood available. The occurrence of this event was significantly higher in treatments with greater amounts of wood. Thus, $N$. corniger adjusts its mass recruitment behavior in response to available food amount, which should be considered when developing baiting system for its control.
\end{abstract}

KEYWORDS: Arboreal-nesting termite. Food availability. Foraging decisions. Xylophagous termite.

\section{INTRODUCTION}

$\begin{array}{cc}\text { The arboreal termite species } & \begin{array}{l}\text { Nasutitermes } \\ \text { corniger }\end{array} \text { (Motschulsky) }\end{array}$
Nasutitermitinae) is the most widely distributed one, and it is found in the Meso-American region, from Southern Mexico to Panama, and also in South America (ATKINSON; ADAMS, 1997; CONSTANTINO, 2002; TORALES, 2002; SCHEFFRAHN et al., 2005; SANTOS et al., 2017; CONSTANTINO, 2019). Moreover, N. corniger causes great damage in urban zones in the entire Neotropical region; and it is seen as a severe pest in some South American countries, such as Argentina, and in many Brazilian states, where it causes damage to timber used in construction sites and for furniture manufacture (BANDEIRA et al., 1989; BANDEIRA; MIRANDA; VASCONCELLOS, 1998; MILL, 1991; MENEZES; AGUIARMENEZES; BICALHO, 2000; COSTALEONARDO, 2002; TORALES, 2002; ALBUQUERQUE et al., 2012). Originally, this termite was considered non-discriminatory among wood of different plant species (BUSTAMANTE, 1993); however, Gazal, Bailez and Viana-Bailez (2010) have shown that wood of Eucalyptus grandis W. Hill ex Maiden (Myrtaceae) was more severely attacked than woods of Pinus elliottii Engel. (Pinaceae) and Manilkara huberi (Ducke) A. Cheval (Sapotaceae), when they were simultaneously offered.

It is hard controlling $N$. corniger because of the high rates of infestation relapses, which are mainly caused by the construction of polycalic nests, which are often far from where they attack and damage the cellulosic materials (COSTALEONARDO, 2002). Thus, urban infestations with $N$. corniger have been controlled through the adoption of methods that compromise environmental sustainability, since they are based on preparing chemical barriers in the soil through the application of high-residual effect insecticides and on chemically treating the timber (United Nations Environment Programme [UNEP], 2000; 
FONTES; MILANO, 2002; GEROZISIS; HADLINGTON; STAUNTON, 2008).

Understanding termites' process to select food sources demands knowing the mechanisms responsible for the repellency or attraction of a food stimulus (SUOJA et al., 1999). Attraction is defined as the action that triggers movements driven towards the stimulus and repellency is the very opposite of it (KENNEDY, 1978; MATTHEWS; MATTHEWS, 1978). Often times, these two actions take part in the process to recruit termites to the food source (SUOJA et al., 1999); besides, they depend on the chemical and physical properties of the wood (PERALTA et al., 2003; SOUZA et al., 2009; PAES et al., 2015).

Laboratory studies revealed that the foraging process carried out by $N$. corniger is selective when it comes to wood species, this termite rather attacks intermediate-density wood, as well as wood presenting high amounts of secondary metabolites, such as E. grandis (GAZAL; BAILEZ; VIANA-BAILEZ, 2010; GAZAL et al., 2012). This termite also attacks both dry and moistened wood, either manufactured or not (BANDEIRA; MIRANDA; VASCONCELLOS, 1998). Nevertheless, this termite species prefers wood that has undergone some sort of deterioration, and that is why it is considered a selective species when it comes to the degree of wood deterioration (BUSTAMANTE, 1993; GAZAL et al., 2012). However, any information was not found about whether the foraging behavior of $N$. corniger can be regulated by volume or amount of the wood.

However, the amount of food available also seems to be one of the main criteria for food resource selection and finding by some termite species (SUOJA et al., 1999, EVANS et al., 2005, INTA et al., 2007, OBERST; LAI; EVANS, 2018). For example, the amount of wood available regulates how severely Coptotermes formosanus Shiraki (Rhinotermitidae) build foraging tunnels (HEDLUND; HENDERSON, 1999). Similarly, Cristaldo et al. (2018) have observed that the number of worker of Nasutitermes aff. coxipoensis (Holmgren) (Termitidae) has linearly increased due to increased food-source density $(0.32,0.64$ and 1.92 baits $/ \mathrm{m}^{2}$ ). The information about the mechanisms of food exploration by termites can help develop more environmentally friendly control methods, such as toxic bait system, whose efficiency depending on information about their recruitment and orientation behavior.

In this context, the aim of the present study was to evaluate the effects of the amount of wood available on the foraging behavior of $N$. corniger under controlled environmental conditions in laboratory.

\section{MATERIAL AND METHODS}

\section{Collection of termite colonies}

Nasutitermes corniger nests $(40 \mathrm{~cm}$ wide and approximately $60 \mathrm{~cm}$ tall) with adult and active colonies (with winged termites) were removed from trees at Frei Leão Vellozzo Park, between December 2016 and May 2017. The park is managed by UFRJ and is located in Península do Catalão, Rio de Janeiro County, Rio de Janeiro State, Brazil (2250'44” S, 4313'19” W). Taxonomic identification was carried out based on the nest architecture described by Thorne (1981) and on examining the collected soldiers, as well as on the description by Scheffrahn et al. (2005). The collected nests were placed in 100-1 black plastic bags and stored in cardboard boxes, in order to avoid damages during transportation to the laboratory of Centro Integrado de Manejo de Pragas (CIMP) do Departamento de Entomologia e Fitopatologia da Universidade Federal Rural do Rio de Janeiro (UFRRJ) - Integrated Pest Management Center of Entomology and Phytopathology Department of Federal Rural Rio de Janeiro University (UFRRJ), in Seropedica County, Rio de Janeiro State, Brazil.

\section{Termite colony maintenance in laboratory}

Each of the collected nests was placed in transparent glass cube $(50.0 \mathrm{~cm} \times 50.0 \mathrm{~cm} \times 60.0 \mathrm{~cm}$ height) connected to foraging arenas after they were taken to the laboratory. The cube was held by a styrofoam plate covered with a layer $(5.0 \mathrm{~cm})$ of sterilized sand. The termites had free access to the foraging arena through a silicone hose $(\varnothing=8.0 \mathrm{~mm}$; length $=10 \mathrm{~cm}$ ) connected to a black PVC pipe inserted in the exit of the glass cube. Each foraging arena consisted of a basis made out of a glass plaque $(50.0 \times 40.0 \mathrm{~cm})$ and a perimeter wall $(5.0 \mathrm{~cm}$ tall). The arena was placed over an acrylic tube $(\varnothing=10.0$ $\mathrm{cm}$ and length $=20.0 \mathrm{~cm}$ ) so that the cube exit was at the same height of the top of the arena's wall (GAZAL; BAILEZ; VIANA-BAILEZ, 2010). A glass ramp was connected from the tip of the silicon hose to the arena in order to allow termites to have access to foraging arena. The ramp consisted of two transparent glass plaques $(4.0 \mathrm{~cm} \times 4.0 \mathrm{~cm}$ and 6.0 $\mathrm{cm} \times 4.0 \mathrm{~cm}$ ) fixed with epoxy adhesive (Durepoxi ${ }^{\circledR}$ ).

Termites were stopped from escaping by a transparent adhesive tape (5 $\mathrm{cm}$ wide) glued on the upper edge of the glass cube wall - the sticky side 
Influence of the amount...

of the tape was turned to the inside of the cube. Pieces of Pinus sp. wood were moistened and made available as food in the arenas. A PET bottle cap, filled with water, was placed by the wood blocks in order to provide humidity to the foraging arena. The nests were stored in a room under controlled temperature $\left(25 \pm 5^{\circ} \mathrm{C}\right)$, relative humidity $(80 \pm 5 \%)$ and 10:14-hour (light/dark) photoperiod at CIMP/UFRRJ. The wood blocks and the sand in each glass cube (holding a nest) were moistened with distilled water on a daily basis. The experiments were carried out one week after the nests were taken to the laboratory.

\section{Bioassay}

Tests were carried out in the foraging arenas of $N$. corniger, based on the methodology described by Souza et al. (2018). The connection between nest and foraging arena was blocked with hydrophilic cotton, 30 minutes before the test had started, in order to block termites' access to the arena. Next, the food was removed from the arena and replaced by blocks of $E$. grandis wood (14\% humidity) (5.0 $\mathrm{cm} \times 2.5 \mathrm{~cm} \times 2.0 \mathrm{~cm}$ ) at four different amounts: 1) One wood block, 2) Two wood blocks, 3) Three wood blocks and 4) Four wood blocks. Treatments were based on situation of choice over glass plaques $(7.0 \mathrm{~cm} \times 4.0 \mathrm{~cm})$; the plaques were connected to other glass plaques $(10.0 \mathrm{~cm} \times 4.0 \mathrm{~cm})$. These plaques were in contact to another glass plaque $(35.0 \mathrm{~cm} \times 4.0 \mathrm{~cm})$, which was placed perpendicular to termites' access to the arena. The glass plaques were arranged over plastic caps $(2.8 \mathrm{~cm} \mathrm{x} 2.8 \mathrm{~cm} \mathrm{x}$ $2.0 \mathrm{~cm}$ ) in order to avoid the access of termites on the basis of the foraging arena to the experimental plaques. Treatments' position in the arena was randomly changed between tests. Tests started when termites' access to the arena was free, they were carried out with $20 \mathrm{~N}$. corniger nests.

The time needed to observe the following behavioral events was recorded throughout each test with a chronometer (TRANIELLO, 1981; GAZAL; BAILEZ; VIANA-BAILEZ, 2010): initial exploration (random arrival of the first soldier to the treatment), initial recruiting (arrival of the first worker to the treatment) and mass recruiting, which was observed when there was a continuous flow of workers to the treatment and a delimited track over the glass plaque due to feces deposition (arrival of a
SOUZA, T. S. et al.

massive number of workers at the treatment). Occurrence rates recorded for these events in each treatment were calculated through the total number of blocks and the occurrence of behavioral events divided by the total number of blocks available in each treatment $(n=20)$, multiplied by 100 . The time taken to observe the behavioral events was counted in a cumulative way, based on the occurrence of events.

The recruited termites found over the glass plaques and the wood blocks were removed after 60 minutes of observation; the number of termites on each treatment was determined, as well as the number of termites (soldiers and workers) recruited to the glass plaque+treatment and the number of gnawing workers (when they were chewing on the wood) in the treatments.

\section{Statistical analysis}

The rate of initial exploration occurrences, of initial recruiting and of workers' mass recruiting was compared through Chi-squared test. Due to lack of normal distribution (KolmogorovSmirnov/Lilliefors at 5\%), data about time, number of gnawing workers, number of workers, number of soldiers and the total number of recruited termites (glass plaques+treatment) were compared through Kruskal-Wallis test $(p<0.05)$. The analyses were carried out in the STATISTICA 10.0 and BioStat ${ }^{\circledR}$ 5.3 software.

\section{RESULTS}

The three behavioral events (initial exploration, initial recruiting and mass recruiting) were shown by $N$. corniger foragers regardless of the amount of E. grandis wood. However, the occurrence recorded for initial exploration and initial recruiting was similar between different wood amounts $\left(\chi^{2}=2.2\right.$; g.l. $=3$; n.s. and $\chi^{2}=0.4 ;$ g.1. $=3$; n.s., respectively). On the other hand, the mass recruiting of $N$. corniger workers was greater in the treatment with four wood blocks (13/20) than in treatments with two blocks $(9 / 02)$ and 1 block (7/20) $\left(\chi^{2}=7.3\right.$; g.l. $=3 . p<0.01$, Figure 1). Nevertheless, the mass recruitment of $N$. corniger was similar between the treatment with two wood blocks $(9 / 20)$ and the one with only one block of it (7/20). 


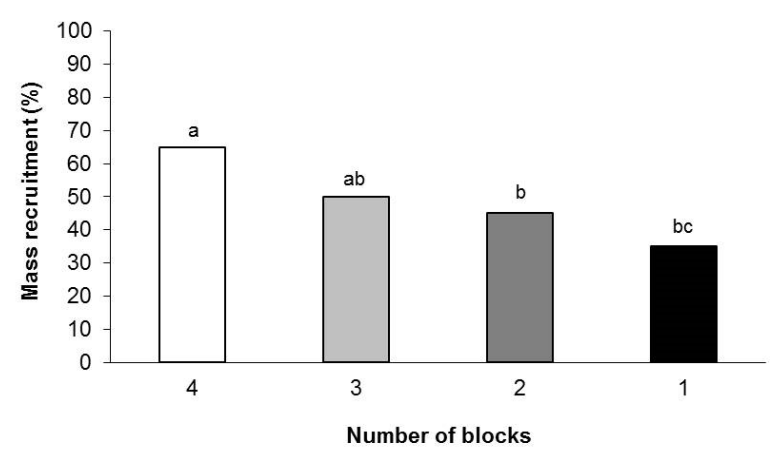

Figure 1. The rate of mass recruitment of Nasutitermes corniger $(\mathrm{n}=20)$ on Eucalyptus grandis wood blocks $(5.0 \mathrm{~cm} \times 2.5 \mathrm{~cm} \times 2.0 \mathrm{~cm})$ provided at four different amounts.

Different letters indicate significant difference between the treatments based on the $\chi^{2}$ Test; $p<0.01$.

The amount of wood did not influence time latency for the performance of the three behavioral events. The initial exploration happened $15.7 \pm 0.8$ min after the test had started, on average; initial recruiting started after $28.1 \pm 0.8 \mathrm{~min}$, and workers' mass recruiting started $46.3 \pm 1.0 \mathrm{~min}$ after the test had begun (Table 1).

Table 1. Elapsed time (mean $\pm \mathrm{SE}$, in minutes) from the beginning of the test until the occurrence of foraging behavior events by Nasutitermes corniger $(\mathrm{n}=20)$ on wood blocks of Eucalyptus grandis provided at four different amounts under situation of choice throughout 60 minutes of observation.

\begin{tabular}{lccc}
\hline Amount of wood blocks $\mathbf{5 . 0}$ & \multicolumn{3}{c}{ Behavioral event $^{\mathbf{1}^{\mathbf{1}}}$} \\
\cline { 2 - 4 } $\mathbf{x} \mathbf{2 . 5} \mathbf{2 . 0} \mathbf{~ c m})$ & Initial exploration & Initial recruitment & Mass recruitment \\
\hline 1 block & $16.5 \pm 1.0 \mathrm{a}$ & $28.4 \pm 0.8 \mathrm{a}$ & $39.3 \pm 0.9 \mathrm{a}$ \\
2 blocks & $18.0 \pm 0.8 \mathrm{a}$ & $31.7 \pm 0.8 \mathrm{a}$ & $50.5 \pm 1.1 \mathrm{a}$ \\
3 blocks & $13.2 \pm 0.7 \mathrm{a}$ & $25.9 \pm 0.7 \mathrm{a}$ & $44.0 \pm 1.0 \mathrm{a}$ \\
4 blocks & $14.9 \pm 0.8 \mathrm{a}$ & $26.5 \pm 0.7 \mathrm{a}$ & $51.3 \pm 1.1 \mathrm{a}$ \\
\hline
\end{tabular}

${ }^{1}$ Means followed by the same letter in the column do not differ from each other in the Kruskal-Wallis test $(\mathrm{p}<0.05)$.

The total number of recruited termites after 60 minutes for the treatments with one $(73.6 \pm 5.7)$, two $(113.9 \pm 6.3)$, three $(219.7 \pm 15.1)$ and four (243.8 \pm 12.9$)$ wood blocks was similar $\left(\mathrm{H}_{3,48}=4.6\right.$, n.s.). The total number of recruited soldiers and workers after 60 minutes was also similar $\left(\mathrm{H}_{3,48}=\right.$ 5.0, n.s. and $\mathrm{H}_{3,48}=4.1$, n.s., respectively) (Table 2).

Out of the total number of workers, the number of gnawing workers exploring the treatment was $56.8 \pm 4.8,91.3 \pm 5.5,187.6 \pm 12.9$ and $208.8 \pm$ 11.5 for treatments with $1,2,3$ and 4 wood blocks, which corresponds to $92.7 \%, 95.6 \%, 99.3 \%$ and $98.7 \%$ of the total number of recruited workers, respectively. However, the number of gnawing workers on the treatments with 1,2 3 and 4 wood blocks was similar $\left(\mathrm{H}_{3,48}=4.5\right.$, n.s.) (Table 2).

Table 2. Total number of termites, number of soldiers, number of workers and number of exploring workers from the beginning of the test until the occurrence of foraging behavior events shown by Nasutitermes corniger $(\mathrm{n}=20)$ on the wood species Eucalyptus grandis provided at four different amounts under situation of choice throughout 60 minutes of observation.

\begin{tabular}{lcccc}
\hline $\begin{array}{c}\text { Amount of wood blocks } \\
(\mathbf{5 . 0} \mathbf{2 . 5} \mathbf{2 . 0} \mathbf{~ c m )}\end{array}$ & $\begin{array}{c}\text { Number of } \\
\text { termites } \\
(\mathbf{m e a n} \pm \mathbf{S E})\end{array}$ & $\begin{array}{c}\text { Number of } \\
\text { soldiers } \\
(\mathbf{m e a n} \pm \mathbf{S E})\end{array}$ & $\begin{array}{c}\text { Number of } \\
\text { workers } \\
(\mathbf{m e a n} \pm \mathbf{S E})\end{array}$ & $\begin{array}{c}\text { Number of } \\
\text { exploring } \\
\text { workers } \\
\text { (mean } \pm \text { SE) }\end{array}$ \\
\hline 1 block & $73.6 \pm 5.7 \mathrm{a}$ & $12.3 \pm 0.7 \mathrm{a}$ & $61.3 \pm 5.1 \mathrm{a}$ & $56.8 \pm 4.8 \mathrm{a}$ \\
2 blocks & $113.9 \pm 6.3 \mathrm{a}$ & $18.5 \pm 0.9 \mathrm{a}$ & $95.5 \pm 5.6 \mathrm{a}$ & $91.3 \pm 5.5 \mathrm{a}$ \\
3 blocks & $219.7 \pm 15.1 \mathrm{a}$ & $30.8 \pm 2.1 \mathrm{a}$ & $188.9 \pm 13.0 \mathrm{a}$ & $187.6 \pm 12.9 \mathrm{a}$ \\
4 blocks & $243.8 \pm 12.9 \mathrm{a}$ & $32.3 \pm 1.5 \mathrm{a}$ & $211.5 \pm 11.7 \mathrm{a}$ & $208.8 \pm 11.5 \mathrm{a}$ \\
\hline
\end{tabular}

Means followed by the same letter in the column did not differ from each other in the Kruskal-Wallis test $(\mathrm{p}<0.05)$. 


\section{DISCUSSION}

The similarity between the initial exploration and initial recruiting shown by $N$. corniger suggests that the amount of wood available does not influence the location and recognition of food sources. However, the greatest occurrence of mass recruitment of workers to the largest quantity of wood indicates that after the recognition of the wood, discrimination occurs in the acceptance of this food source. The amount of food is considered as one of the essential criteria used by underground and dry-wood termites at the time to select a food source (SUOJA et al., 1999; GRACE; CAMPORA, 2005; EVANS et al., 2005; INTA et al., 2007; OBERST; LAI; EVANS, 2018). According to Grace and Campora (2005), after the underground termite species C. formosanus sets many eating locations, workers' efforts are triggered, since not all food sources can be equally accepted by representatives of this species. Thus, $C$. formosanus changes its recruiting behavior, depending on the quality and amount of food (WALLER; LA FAGE, 1987). Almeida et al. (2018) showed that the foraging behavior of Nasutitermes aff. coxipoensis is regulated by food resource availability in experiments carried out in the Brazilian Northeastern region. It happened due to the increased food density, which reduced the foraging area available to these termites. The same behavior was observed in Cornitermes cumulans (Kollar) representatives, when the amount of food resources increased (ARAÚJO; ARAÚJO; DE SOUZA, 2011).

Soldiers' recruitment in treatments with different amounts of wood was also equivalent, and this outcome indicates that this caste has actively participated in the foraging process at all amounts of wood available, due to the escort by the recruited workers and the gnawing workers who explored the wood blocks. This soldier behavior was also observed by Lima and Costa-Leonardo (2014) in underground termite species and by Souza et al. (2018) in N. corniger colonies.

According to Delaplane and La Fage (1987) and Jones, Trosset and Nutting (1987), when termites cover a location where there is a favorable food source, they become quite loyal to this source; however, the similar number of recruited $N$. corniger foragers in treatments with different amounts of wood blocks suggests that this species does not show recruiting loyalty to certain amount of wood. On the other hand, the underground termite species Coptotermes gestroi (Wasmann) (Rhinotermitidae) and Heterotermes tenuis (Hagen)
(Rhinotermitidae) concentrated their efforts on the first food found when they did not have access to other food sources (LIMA; COSTA-LEONARDO, 2014).

The similar number of gnawing workers exploring the wood blocks is not associated with the amount of wood available. This outcome indicates that $N$. corniger does not set the adequacy of food sources available, based on the amount of such sources. Thus, the amount of wood does not regulate wood exploration by $N$. corniger, likely because workers lay similar saliva concentrations on the wood, regardless of the amount of wood available. $N$. corniger workers have substances in their saliva that have phage- or arresting-stimulating action in the location where it is laid on, and these substances can be the trigger to increase the number of gnawing workers exploring the wood blocks (SILVA, 2008). Some termites species, such as those living in moistened wood like Schedorhinotermes lamanianus (Sjöstedt) (Rhinotermitidae) and underground species such as Reticulitermes flavipes (Kollar) (Rhinotermitidae) and C. gestroi, also have non-volatile substances in their saliva, which are phage-stimulants that increase workers gathering on the food source (KAIB; ZIESMANN, 1992; REINHARD; HERTEL; KAIB, 1997; REINHARD; KAIB, 2001; CASARIN; ARAB; COSTALEONARDO, 2003). These chemical signs facilitate the location, recruitment and exploration of food sources (LIMA; COSTA LEONARDO, 2012).

In this work it was verified that when timber in different quantities are offered to the termites simultaneously, these initially represent for $N$. corniger sources of food of equivalent interest. However, in the process of accepting these sources, there is competition that causes differences in the proportion of mass recruitment. In the last phase of foraging, termites again lack preference in the exploitation of these woods.

\section{ACKNOWLEDGMENTS}

We thank the Coordenação de Aperfeiçoamento de Pessoal de Nível Superior Brasil (CAPES), for the magister science scholarship awarded to the first author. Thanks to Angela Iaffe (Agronomic Engineer of the Horto Florestal at UFRJ) for acting as an intermediary with Parque Frei Leão Vellozzo so the termite colonies could be collected, Flávio (employee of the staff of the park), the Divisão de Segurança (DISEG) at UFRJ, to João Vicente de Figueiredo Latorraca for allowing to use of the carpentry at the 
Department of Forest Products (DPF) at UFRRJ, and we are also grateful to its carpentry staff. This study was financed in part by CAPES - Finance Code 001 .

RESUMO: A escassez ou abundância de alimento são fatores que regulam o forrageamento do térmitas em geral. No presente estudo, avaliou-se a influência de quatro quantidades de madeira de Eucalyptus grandis em eventos comportamentais do forrageamento exibidos por operárias e soldados de Nasutitermes corniger em testes de laboratório. Os testes foram realizados com colônias maduras e ativas de $N$. corniger presentes em ninhos coletados a campo, os quais foram acondicionados em cubas de vidro conectadas a arenas testes. Blocos de madeira de mesma dimensão foram ofertados aos térmitas em quatro quantidades: 1, 2, 3 e 4 blocos/arena, com 5 repetições. Cada teste durou 60 minutos e consistiu na observação ou não da ocorrência de eventos comportamentais exibidos pelos forrageadores quando foi dado acesso a cada tratamento. Quando cada evento foi observado, o tempo de sua duração foi registrado. Ao final de cada teste registrou-se, em cada tratamento, o número de térmitas forrageadores recrutados e o número de operários consumindo os blocos. Observou-se que $N$. corniger exibiu os três eventos comportamentais em todos os tratamentos. Todavia, não houve diferença significativa entre os tratamentos com relação à ocorrência dos dois primeiros eventos, aos tempos transcorridos desde o início do teste até a ocorrência de cada evento, aos números de térmitas recrutados e ao número de operários em roedura. Apenas a ocorrência de recrutamento em massa dos operários foi influenciada pela quantidade de madeira ofertada, sendo que foi significativamente superior quando se ofertou os blocos de madeira na maior quantidade. Dessa forma, $N$. corniger ajusta seu comportamento de recrutamento em massa em resposta a quantidade de alimento disponível, o que deve ser considerado ao se desenvolver um sistema de isca para seu controle.

PALAVRAS-CHAVE: Cupim de nidificação arbórea. Cupim xilófago. Decisões de forrageamento. Disponibilidade de alimento.

\section{REFERENCES}

ALBUQUERQUE, A.C.; MATIAS, G.R.R.S.; COUTO, A.A.V.O.; OLIVEIRA, M.A.P.; VASCONCELLOS, A. Urban Termites of Recife, Northeast Brazil (Isoptera). Sociobiology, Feira de Santana, v. 59, n. 1, p. 183188, 2012. http://dx.doi.org/10.13102/sociobiology.v59i1

ALMEIDA, C.S.; CRISTALDO, P.F.; DESOUZA, O.; BACCI, L.; FLORENCIO, D.F.; CRUZ, N.G.; SANTOS, A.A.; SANTANA, A.S.; OLIVEIRA, A.P.; LIMA, A.P.S.; ARAÚJO, A.P.A. Resource density regulates the foraging investment in higher termite species. Ecological Entomology, United Kingdom, v. 43, p. 371-378, 2018. https://doi.org/10.1111/een.12508

ARAÚJO, A.P.A.; ARAÚJO, F.S.; DE SOUZA, O. Resource suitability affecting foraging area extension in termites (Insecta, Isoptera). Sociobiology, Feira de Santana, v. 57, n. 2, p. 1-13, 2011.

ATKINSON, L.; ADAMS, E.S. The origins and relatedness of multiple reproductives in colonies of the termite Nasutitermes corniger. Proceeding of the Royal Society B: Biological Sciences, United Kingdom, v. 264, $\mathrm{n}$. 1385, p. 1131-1136, 1997. https://doi.org/10.1098/rspb.1997.0156

BANDEIRA, A.G.; GOMES, J.I.; LISBOA, P.L.B.; SOUZA, P.C.S. Insetos pragas de madeiras de edificações em Belém - Pará. Boletim de Pesquisa, 101. Belém: EMBRAPA-CPATU, 1989.

BANDEIRA, A.G.; MIRANDA, C.S.; VASCONCELLOS, A. Danos causados por cupins em João Pessoa, Paraíba - Brasil. In: FONTES, L.R.; BERTI-FILHO, E. (Ed.). Cupins: o desafio do conhecimento. Piracicaba: FEALQ, 1998. pp. 75-85.

BUSTAMANTE, N. C. R. Preferências alimentares de 5 espécies de cupins Nasutitermes Dudley, 1980 (Termitidae: Isoptera) por 7 espécies de madeiras de várzea na Amazônia Central. Dissertação de Mestrado. Manaus: Instituto Nacional de Pesquisas da Amazônia, 1993. 
Influence of the amount...

SOUZA, T. S. et al.

CASARIN, F.E.; ARAB, A.; COSTA-LEONARDO, A.M. Influence of the labial gland's semiochemicals on the feeding behavior of Coptotermes havilandi (Isoptera: Rhinotermitidae). Sociobiology, Feira de Santana, v. 42, n. 2, p. 485-493, 2003.

CONSTANTINO, R. On-line termite database. Brasília: Universidade de Brasília, 2019. Available from: http://164.41.140.9/catal/.

CONSTANTINO, R. The pest termites of South America: taxonomy, distribution and status. Journal of Applied Entomology, United Kingdom, v. 126, p. 355-365, 2002. https://doi.org/10.1046/j.1439$\underline{0418.2002 .00670 . \mathrm{x}}$

COSTA-LEONARDO, A.M. Cupins-praga: morfologia, biologia e controle. Rio Claro: Divisa, 2002.

CRISTALDO, P.F.; ALMEIDA, C.S.; CRUZ, N.G.; RIBEIRO, E.J.M.; ROCHA, M.L.C.; SANTOS, A.A.; SANTANA, A.S.; ARAÚJO, A.P.A. The role of resource density on energy allocation in the Neotropical termite Nasutitermes aff. coxipoensis (Termitidae: Nasutitermitinae). Neotropical Entomology, Londrina, v. 47, n. 3, p. 329-335, 2018. https://doi.org/10.1007/s13744-017-0525-Z

DELAPLANE, K.S.; LA FAGE, J.P. Variance in feeding on equivalent wood blocks by Formosan subterranean termite in laboratory choice tests. Sociobiology, Feira de Santana, v. 13, n. 3, p. 227-233, 1987.

EVANS, T.A.; LAI, J.C.S.; TOLEDANO, E.; MCDOWALL, L.; RAKOTONARIVO, S.; LENZ, M. Termites assess wood size by using vibration signals. Proceedings of the National Academy of Sciences of the United States of America, United States, v. 102, n. 10, p. 3732-3737, 2005. https://doi.org/10.1073/pnas.0408649102

FONTES, L.R.; MILANO, S. Termites as urban problem in South America. Sociobiology, Feira de Santana, v. 40, n. 1, p. 104-151, 2002.

GAZAL, V.; BAILEZ, O.; VIANA-BAILEZ, A.M. Wood preference of Nasutitermes corniger (Isoptera: Termitidae). Sociobiology, Feira de Santana, v. 55, n. 2, p. 433-443, 2010.

GAZAL, V.; BAILEZ, O.; VIANA-BAILEZ, A.M.; AGUIAR-MENEZES, E.L.; MENEZES, E.B. Decayed wood affecting the attraction of the pest arboretum termite Nasutitermes corniger (Isoptera: Termitidae) to resource foods. Sociobiology, Feira de Santana, v. 59, n. 1, p. 287-295, 2012.

http://dx.doi.org/10.13102/sociobiology.v59i1.684

GEROZISIS, J.; HADLINGTON, P.; STAUNTON, I. Urban pest management in Australia. Sydney:

University of New South Wales Press, 2008.

GRACE, J.K.; CAMPORA, C.E. Food location and discrimination by subterranean termites (Isoptera: Rhinotermitidae). In: LEE, C.-Y.; ROBINSON, W.H. (Ed.). Food Location and Discrimination by Subterranean Termites (Isoptera: Rhinotermitidae) Perniagaan Ph'ng @ P \& Y Design Network, Malaysia: Proceedings of the Fifth International Conference on Urban Pests, 2005. pp. 437-441.

HEDLUND, J.C.; HENDERSON, G. Effect of available food size on search tunnel formation by the Formosan subterranean termite (Isoptera: Rhinotermitidae). Journal of Economic Entomology, United Kingdom, v. 92, n. 3, p. 610-616, 1999. https://doi.org/10.1093/jee/92.3.610

INTA, R.; LAI, J.C.S.; FU, E.W.; EVANS, T.A. Termites live in a material world: exploration of their ability to differentiate between food sources. Journal of the Royal Society Interface, United Kingdom, v. 4, n. 15, p. 735-744, 2007. https://doi.org/10.1098/rsif.2007.0223

JONES, S.C.; TROSSET, M.W.; NUTTING, W.L. Biotic and abiotic influences on foraging of Heterotermes aureus (Snyder) (Isoptera: Rhinotermitidae). Environmental Entomology, United States, v. 16, n. 3, p. 791795, 1987. https://doi.org/10.1093/ee/16.3.791 
Influence of the amount...

KAIB, M.; ZIESMANN, J. The labial gland in the termite Schedorhinotermes lamanianus (Isoptera:

Rhinotermitidae): morphology and communal food exploitation. Insectes Sociaux, Switzerland, v. 39, p. 373384, 1992. https://doi.org/10.1007/BF01240622

KENNEDY, J.S. The concepts of olfactory 'arrestment' and 'attraction'. Physiological Entomology, United Kingdom, v. 3, n. 2, p. 91-98, 1978. https://doi.org/10.1111/j.1365-3032.1978.tb00138.x

LIMA, J.T.; COSTA-LEONARDO, A.M. Tunnelling behaviour of the Asian subterranean termite in heterogeneous soils: presence of cues in the foraging area. Animal Behaviour, United States, v. 83, n. 5, p. 1269-1278, 2012. https://doi.org/10.1016/j.anbehav.2012.02.020

LIMA, J.T.; COSTA-LEONARDO, A.M. Foraging in subterranean termites (Isoptera: Rhinotermitidae): how do Heterotermes tenuis and Coptotermes gestroi behave when they locate equivalent food resources? Bulletin of Entomological Research, United Kingdom, v. 104, n. 4, p. 525-533, 2014. https://doi.org/10.1017/S0007485314000297

MATTHEWS, R.W.; MATTHEWS, J.R. Insect behavior. 1st ed. New York: John Wiley \& Sons, 1978.

MENEZES, E.B.; AGUIAR-MENEZES, E.L.; BICALHO, A. Cupim arbóreo Nasutitermes spp., mais uma ameaça nas cidades. Vetores \& Pragas, Rio de Janeiro, v. 2, n. 6, p. 26-29, 2000.

MILL, A.E. Termites as structural pest in Amazonia, Brazil. Sociobiology, Feira de Santana, v. 19, n. 2, p. 339348, 1991.

OBERST, S.; LAI, J.C.S.; EVANS, T.A. Key physical wood properties in termite foraging decisions. Journal of the Royal Society Interface, United Kingdom, v. 15, n. 149, ID 20180505, 2018.

https://doi.org/10.1098/rsif.2018.0505

PAES, J.B.; BROCCO, V.F.; MOULIN, J.C.; MOTTA, J.P.; ALVES, R.C. Efeitos dos extrativos e da densidade na resistência natural de madeiras ao térmita Nasutitermes corniger. Cerne, Lavras, v. 21, n. 4, p. 569-577, 2015. https://doi.org/10.1590/01047760201521041849

PERALTA, R.C.G.; MENEZES, E.B.; CARVALHO, A.G.; AGUIAR-MENEZES, E.L. Feeding preference of subterranean termites for forest species associated or not a wood-decaying fungi. Floresta e Ambiente, Seropédica, v. 10, n. 2, p. 58-63, 2003. https://www.floram.org/article/588e2205e710ab87018b45fe

REINHARD, J.; HERTEL, H.; KAIB, M. Feeding stimulating signal in labial gland secretion of the subterranean termite Reticulitermes santonensis. Journal of Chemical Ecology, United States, v. 23, n. 10, p. 2371-2381, 1997. https://doi.org/10.1023/B:JOEC.0000006680.96008.48

REINHARD, J.; KAIB, M. Food exploitation in termites: indication for a general feeding-stimulating signal in labial gland secretion of Isoptera. Journal of Chemical Ecology, United States, v. 27, n. 1, p. 189-201, 2001. https://doi.org/10.1023/a:1005636504469

SANTOS, A.F.; CARRIJO, T.F.; CANCELLO, E.M.; CASTRO, A.C.M.-C. Phylogeography of Nasutitermes corniger (Isoptera: Termitidae) in the Neotropical Region. BMC Evolutionary Biology, London, v. 17, p. 112, 2017. https://doi.org/10.1186/s12862-017-1079-8

SCHEFFRAHN, R.H.; KRECEK, J.; SZALANSKI, A.L.; AUSTIN, J.W. Synonymy of Neotropical arboreal termites Nasutitermes corniger and N. costalis (Isoptera: Termitidae: Nasutitermitinae), with evidence from morphology, genetics, and biogeography. Annals of the Entomological Society of America, New York, v. 98, n. 3, p. 273-281, 2005. https://doi.org/10.1603/0013-8746(2005)098[0273:SONATN]2.0.CO;2

SILVA, V.S.G. Comportamento de forrageamento de Nasutitermes corniger (Motschulsky) (Isoptera: Termitidae) e sua ocorrência em áreas urbanas. Tese de Doutorado. Campos dos Goytacazes: Universidade Estadual Norte Fluminense Darcy Ribeiro, 2008. 
SOUZA, J.H.; AGUIAR-MENEZES, E.L.; MAURI, R.; MENEZES, E.B. Susceptibility of five forest species to Coptotermes gestroi. Revista Árvore, Viçosa, v. 33, n. 6, p. 1043-1050, 2009. http://dx.doi.org/10.1590/S0100-67622009000600007

SOUZA, T.S.; GAZAL, V.S.; FERNANDES, V.J.; OLIVEIRA, A.C.C.; AGUIAR-MENEZES, E.L. Influence of Food Resource Size on the Foraging Behavior of Nasutitermes corniger (Motschulsky). Sociobiology, Feira de Santana, v. 65, n. 2, p. 291-298, 2018. http://dx.doi.org/10.13102/sociobiology.v65i2.2844

SUOJA, S.B.; LEWIS, V.R.; WOOD, D.L.; WILSON, M. Comparisons of single and group bioassays on attraction and arrestment of Reticulitermes sp. (Isoptera: Rhinotermitidae) to selected cellulosic materials. Sociobiology, Feira de Santana, v. 33, n. 2, p. 125-135, 1999.

THORNE, B. Differences in nest architecture between the Neotropical arboreal termites $N$. corniger and $N$. ephratae (Isoptera: Termitidae). Psyche, Cambridge, v. 87, p. 223-243, 1981.

https://doi.org/10.1155/1980/12305

TORALES, G.J. Termites as structural pests in Argentina. Sociobiology, Feira de Santana, v. 40, n. 1, p. 191206, 2002.

TRANIELLO, J.F.A. Enemy deterrence in the recruitment strategy of a termite: soldier organized foraging in Nasutitermes costalis. Proceedings of the National Academy of Sciences of the United States of America, United States, v. 78, n. 3, p. 1976-1979, 1981. https://doi.org/10.1073/pnas.78.3.1976

United Nations Environment Programme (UNEP). Finding alternatives to persistent organic pollutants (POPs) for termite management, 2000. https://nature.berkeley.edu/upmc/documents/UN termite.pdf

WALLER, D.A.; LA FAGE, J.P. Nutritional ecology of termites. In: SLANSKY JR., F.; RODRIGUEZ, J.G. (Ed.). Nutritional ecology of insects, mites, spiders, and related invertebrates. New York: John Wiley \& Sons, 1987. pp. 487-532. 